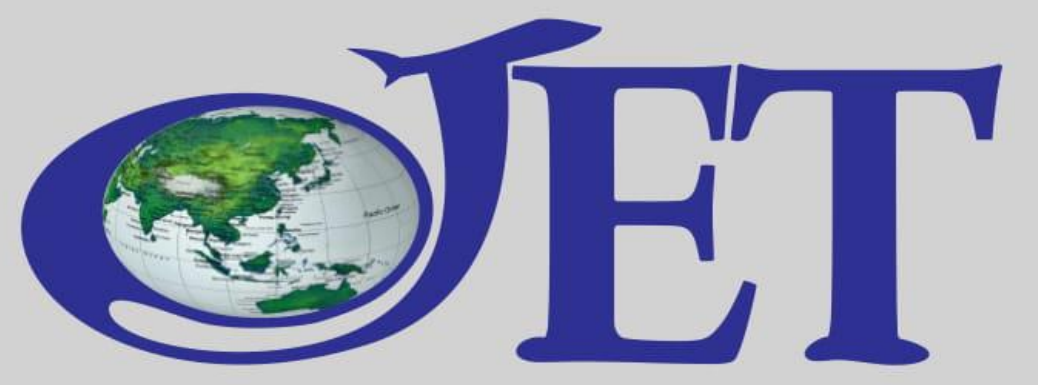

a

ISSN 20809628

triannual

publication

on the study of

English Language Teaching

Volume 3, Number 3, October 2017

\title{
The Effectiveness of Picture: An Empirical Evidence in Vocabulary Mastery
}

\author{
Ema Maritha \\ ema_maritha@gmail.com \\ SD Negeri Karawang \\ Saniago Dakhi \\ saniagonias@gmail.com \\ Universitas Kristen Indonesia
}

\begin{abstract}
This action research was conducted to improve the students' English vocabulary mastery by using picture. To achieve the objective, data were collected through the test, questionnaire and observation from 21 students in third graders of SDN Karawang Kulon II. The outcomes of the research showed that students' vocabulary mastery got improved. This improvement is seen from the mean score of the test, i.e. 56.19 (Pre-test I), 81.90 (Post-test II), and 94.29 (Post-test II). Additionally, the result of questionnaire on the vocabulary teaching applying picture also shows the positive changes. The above data indicates that vocabulary picture can be effective media for vocabulary learning English. However, it is expected that other researchers could conduct similar researches on the related issues to develop it.
\end{abstract}

Keywords: experimental research, pictures, vocabulary

\section{Introduction}

English is the first international language in the world (Kim, 2011). Realizing its high importance, English has been learned started from kindergarden until university. Most of the 
EFL learners in all levels of education assume that English is difficult. The reasons are varied and different ranging from the gramatical structure confusion, complicated pronunciation, and the lack of vocabulary. In order to master English, parents do many things to encourage their children to learn English in early stage or primary school. In this age children have good thought stimulation in absorbing knowledge. Primary school is an important stage for children.

One of the skill language that needs to be paid attention in teaching English is vocabulary. This is in parallel with what is stated by Zhihong (2000) that without sufficient vocabulary, one cannot communicate or expres, one cannot communicate or express ideas effectively. Griva (2009) state that vocabulary learning has been considered fundamental and inseparable aspect of teaching. It means that having lack of vocabulary might prevent students from learning a foreign language. In others words, when students do not have adequate amount of vocabulary, they cannot communicate with each other and express their ideas well. Learning and teaching vocabulary are greatly significant in learning a language because by acquiring sufficient vocabularies, a student is easier to understand the grammar rules of language and then be able to communicate properly. As stated by Wallace (2002), one can know the grammar rules of a language and yet not be able to communicate in it. On the other hand, with a command of vocabulary one needs in certain situation, some form of communication is possible. Therefore as English teacher, one must explore the materials of teaching, especially in the study of vocabulary. Teachers are suggested to methods and techniques in teaching vocabulary in to help students in their learning. It is teacher's task to make students easier to learn vocabulary.

According to McCarten (2007) learning vocabulary is largely about remembering, and students generally need to see, say, and write newly-learned words many times before they can be said to have learned them. For this reason, in teaching vocabulary, teachers have to consider approaches to teaching vocabulary that can help students store the introduced vocabulary into their long-term memory. By applying such vocabulary teaching technique, it is expected students' vocabulary will add up through their learning.

Language is biologically inherited but it is mastered through some efforts (Dakhi, 2016). To develop students' speaking competences, therefore, teachers should equip the students in the vocabulary. In other words, students' competence should be directed to the use of vocabulary depended on their learning level. To young learners, for instance, the types of vocabulary to be taught should also be related teaching method. Even if, necessary, it can be 
conducted using proper media. However, in fact, many teachers might not realize the importance of considering the types of vocabulary and teaching method when teaching. It can be evidenced through the achievement scores of the students in english learning or of one or more language skills or subskills. It is important to be taken into account as what Dakhi (2010) stated that a good status of language is affected by its speaker's competence and performance. The failure of achieving the achievement score based on the learners' failure in achieving the standard of minimal achievement score prevailed in some formal educational institutions. Another evidence indicating the impacts of teachers' ignorance of the importance of the vocabulary and teaching method was the lack of interest, motivation, and enjoyment of the students in English learning. to such students condition of learning, teacher should take any efforts into account.

Based on the phenomena of teaching and learning previously described, the researcher was inspired to conduct a study. The study was focused on vocabulary improvement of the third graders at SDN Karawang Kulon II. The decision to take the focus and students were based on the English teacher's information and complaint toward: 1) the low scores of English learning the students achieved and 2) the students lack of interest in English learning. It was informed that this condition was clearly seen through their conversation one another; bothering one another operating the mobile phones; making noisy; expressing boredmood, etc. Based on the information, the researcher decided to help the teacher by employing a study, by implementing a classroom action researcher. In employing the classroom action research, the researcher used pictures as the teaching medium in teaching vocabulary.

\section{Methodology}

This research was a Classroom Action Research (CAR). Consequently, it used mixed method: quantitative and qualitative. The quatitative method was used to collect the quantitative data. The quantitative data were taken from the scores of the Pre-test and Post-test conducted prior to and post teaching in the Cycle I and Cycle II. The qualitative method was implemented to collect the thematic or descriptive data based on the observer and teacher's notes as well as the students' perceptions through questionaire administered. This research was employed in two cycles, based on Ferrance's (2000) action research cycles, consisting of four phases of action: planning, acting, observing and reflecting. 


\section{Planning}

In this phase the reseacher conducted some steps as follows: 1) preparing action plan;

2) teaching materials; 3) test and non-test material evaluations. Action plan is designed to help the researcher do the activities in the class.

\section{Acting}

At this stage the the planned actions were employed. The researcher taught the students. It took 70 minutes in every cycles. Action process in every meeting was conducted through introduction of new words. The researcher asked students about the materials. This was done to determine the students' understanding towards the material. After explaining the instruction through the pictures the researcher asked the students to answer the topic given. The purpose of teaching vocabulary using pictures was to help the students get easier to recognize and remember the vocabulary being learned and made the learning process more fun.

\section{Observing}

In this phase the researcher used observation notes and questionnaire. The observation notes were taken from the observer and the researcher herself based on the situation and condition of the students and classroom as well as the researcher's performence along with the learning process. The quetionnaire also was used to take inputs from the students.

\section{Reflecting}

All the data collected, including the pre-test, observer and teacher's notes as well as the questionnaire were then taken into account for reflection. It was the moment for the researcher to evaluate the learning activities, condition, and results of learning. All the data were made basis to design planning and acting in the next cycle. To simply put, the research was conducted through the research design displayed in Figure 1. 


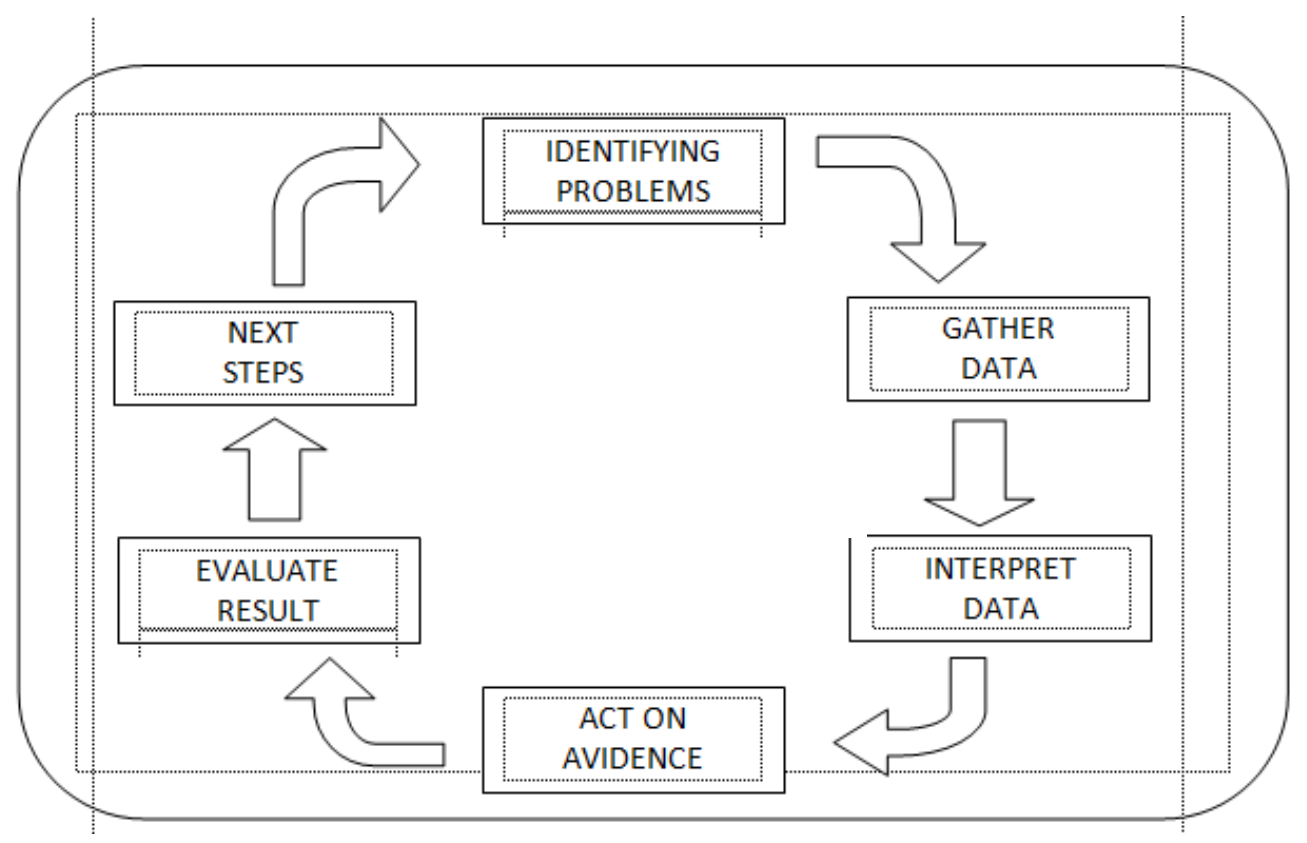

Figure 1: Research Procedure

The participants were third graders of 2016/2017 batch, and the total number of students was 21 , consisting of 8 males and 13 females.

Table 1:

The Demographie Data of Research

\begin{tabular}{cccc}
\hline No & Participants & $\mathrm{n}$ & Percentage \\
1 & Male & 8 & $38.10 \%$ \\
2 & Female & 13 & $61.90 \%$ \\
\hline & Total & 21 & 100.00 \\
\hline
\end{tabular}

The data of this research were collected using test, quesstionaire, and observation techniques. This test technique was realized through a set of questions consisting of 20 items. The test was employed in Pre-test and Post-test. The quetionnaire technique was actualized through 5 questions, employing "yes" and "no" options. The questions were designed in such a way to represent their achievement in vocabulary learning using pictures. In addition, the last technique, observation, was realized through by observing the research's performance, students' activities, and classroom atmosphere by an observer (the researcher's colleague in that school) and by the researcher herself. All the observed conditions and situations were then taken into notes. 
The data collected were then analyzed using quantitative and qualitative descriptive analysis. The former technique was used to analyze the quantitative data and displayed the result in frequency, mean, minimum, and maximum score. The other one used to analyze the descriptive data, those the observer's and researcher's notes and descriptively presented.

After the researcher had got collected the score data, the researcher interpreted them based on the category of achievement prevailed at SDN Karawang Kulon II. The category is as displayed in Table 3.1. The minimal score achievement was based on that prevailing at SDN Karawang Kulon II, that is 75.00 .

Table 2:

Score Category

\begin{tabular}{ccc}
\hline No & Criteria & Range \\
\hline 1 & Very Good & $81.00-100.00$ \\
2 & Good & $70.00-80.00$ \\
3 & Fair & $51.00-69.00$ \\
4 & Bad & $40.00-50.00$ \\
\hline
\end{tabular}

\section{Result and Discussion}

Table 3:

Student Pre Test Scores I ( N=21)

\begin{tabular}{cccccc}
\hline Test & Minimum & F & Maximum & f & Mean \\
\hline Pre-Test & 40.00 & 3 & 80.00 & 2 & 56.19 \\
\hline
\end{tabular}

Table 3 shows there were only two students achieving the minimum scores (80.00). The other 19 participants got below the minimal scores. Based on the table it can be stated that there were two participants categorized "Good".

Table 4:

Students' Score Achievemen tin Post Test in Cycle 1 ( N=21)

\begin{tabular}{cccccc}
\hline Test & Minimum & f & Maximum & f & Mean \\
\hline Post Test 1 & 65.00 & 1 & 95.00 & 1 & 81.90 \\
\hline
\end{tabular}

Table 4 indicates that only one students got 65.00 as minimum score. Whereas there was one student achieving 95.00 in the maximum score. The average score in the Post-test I reached 81.90 . 
Table 5:

Analysis Result on Questionnaire in Cycle I $(N=21)$

\begin{tabular}{|c|c|c|c|c|c|}
\hline \multirow[b]{2}{*}{ No } & \multirow[b]{2}{*}{ Indicators } & \multicolumn{2}{|c|}{ Yes } & \multicolumn{2}{|c|}{ No } \\
\hline & & $\mathrm{f}$ & $\%$ & $\mathrm{f}$ & $\%$ \\
\hline 1 & $\begin{array}{l}\text { Do you like learning } \\
\text { vocabulary using by pictures? }\end{array}$ & 18 & 85.71 & 3 & 14.29 \\
\hline 2 & $\begin{array}{l}\text { Are you excited when teacher teaches } \\
\text { vocabulary using the pictures? }\end{array}$ & 19 & 90.48 & 2 & $\begin{array}{c}9.5 \\
2\end{array}$ \\
\hline 3 & $\begin{array}{l}\text { Do you memorize more than } 2 \text { words } \\
\text { after learning vocabulary by the } \\
\text { pictures? }\end{array}$ & 15 & 71.43 & 6 & $\begin{array}{c}28.5 \\
7\end{array}$ \\
\hline 4 & $\begin{array}{l}\text { Do you get trouble to pronounce the } \\
\text { words? }\end{array}$ & 3 & 14.29 & 18 & $\begin{array}{l}85 \\
71\end{array}$ \\
\hline 5 & Do you think your vocabulary improve & 16 & 76.19 & 5 & $\begin{array}{c}23.8 \\
1 .\end{array}$ \\
\hline
\end{tabular}

Based on the result of analysis on the questionnaire as shown in Table 5, almost all the students confessed that they liked learning English vocabulary using pictures. When asked if they are excited when taught vocabulary using pictures 90.48\% (19 students) answered "Yes". When responding the questions number 3, and 5, 71.43\% (15 students) and 76.19\% (10 students) confessed to "Yes." When encoutering the question "Do you get trouble in pronouncing the words", 18 of them $(85.71 \%)$ answered "No."

Table 6:

Obsever's Note of the Cycle I

\begin{tabular}{|c|c|c|c|}
\hline No & Observed & Aspect & Note \\
\hline \multirow[t]{5}{*}{1} & Teacher & Subject master mastering & Good \\
\hline & & $\begin{array}{l}\text { Competency in } \\
\text { explaining method }\end{array}$ & $\begin{array}{l}\text { Make sure you have all ready read } \\
\text { the material before you teach }\end{array}$ \\
\hline & & Voice & Slowly please \\
\hline & & Teacher students & Dont stand before the class only. \\
\hline & & Interaction & $\begin{array}{l}\text { Make your time sometimes close } \\
\text { to the students }\end{array}$ \\
\hline 2 & Students & Attitude & $\begin{array}{l}\text { Talking and playing withother } \\
\text { friend }\end{array}$ \\
\hline 3 & Class Atmosphere & Classroom situation & Still Noisy \\
\hline
\end{tabular}

Table 6 contains the observer's note covering the teacher's performance, students' attitude and classroom atmospheres during the learning process in the Cycle I. The table clearly informs that researcher was found not already yet read the material before teaching. Besides, the observer found the researcher taught with loud voice. In addition, the researcher stood too long 
in teaching before the class. Considering the students' attitude, they were found talking and playing with their other friends during the class session. Similarly, it was noted that the classroom situation was so noisy.

Based on the findings on the Pre-test scores, analysis result on the questionnaire, and observer's notes, the researcher did a reflection. Since all of these data still indicated weakness both of the researcher students, the researcher decided to go on the study to the Cycle II.

Table 7:

Students' Achievement in the Post-Test II of the Cycle II

\begin{tabular}{cccccc}
\hline Test & Minimum & F & Maximum & f & Mean \\
\hline Post Test 2 & 80.00 & 4 & 100.00 & 10 & 94.29 \\
\hline
\end{tabular}

Table 7 informs the students scores in the Post-testII. The table shows that there were four students achieving 80.00 (above the minimal score achievement). More interestingly, this is as the minimum scores. In addition, it is also shown that there are ten students with 100.00, and it was the maximum scores. Based on the scores category prevailed in SDN Karawang Kulon II (Table 7), it can be stated that almost all the students achieved "very good criteria."

Table 8:

Analysis Result of Questionnaire in the Cycle II $(N=21)$

\begin{tabular}{|c|c|c|c|c|c|}
\hline \multirow[b]{2}{*}{ No } & \multirow{2}{*}{ Indicators } & \multicolumn{2}{|c|}{ Yes } & \multicolumn{2}{|r|}{ No } \\
\hline & & $\mathrm{f}$ & $\%$ & $\mathrm{f}$ & $\%$ \\
\hline 1 & $\begin{array}{l}\text { Do you like learning English } \\
\text { vocabulary using by the pictures? }\end{array}$ & 21 & 100.00 & 0.00 & 0.00 \\
\hline 2 & $\begin{array}{l}\text { Are you excited when teacher teaches } \\
\text { vocabulary using pictures? }\end{array}$ & 21 & 100.00 & 0.00 & 0.00 \\
\hline 3 & $\begin{array}{l}\text { Do you memorize more than } 2 \text { words } \\
\text { after learning vocabulary using pictures }\end{array}$ & 18 & 85.71 & 3 & 14.29 \\
\hline 4 & $\begin{array}{l}\text { Do you get trouble in pronouncing the } \\
\text { words? }\end{array}$ & 0 & 0.00 & 21 & 100.00 \\
\hline 5 & Do you think your vocabulary improve? & 21 & 100.00 & 0 & 0.00 \\
\hline
\end{tabular}

Table 8 clearly shows data concerned with the students' perceptions or answer toward the question proposed. To the questions number 1 and 2, 21 students (100.00\%) answered "Yes". Encountering the question number 3 and 5, 18 and 21 students answered "Yes". However all participants had no word ponunciation problem (item 4). 
Table 9:

Observer's Note of the Cycle II

\begin{tabular}{clll}
\hline No & \multicolumn{1}{c}{ Observed } & \multicolumn{1}{c}{ Aspect } & \multicolumn{1}{c}{ Note } \\
\hline 1 & Teacher & Subject & Good \\
& & Competency in explaining & You already improved \\
& & Voice & Clear enough \\
& & Student-Teacher interaction & Good \\
2 & Students & Attitude & Students more attentive \\
3 & Class Atmosphere & Classroom situation & Good and conducive \\
\hline
\end{tabular}

Table 9 confirms that teacher mastered very well the subject, teaching competency got improved, the volume of the voice was clear enough, and student-teacher interaction was reasonably acceptable. In addition, the students' learning attitude shows better, and teaching and learning atmosphere were totally conducive and attractive. To sum up, considering the improvement of the students' scores and perceptions as well as the researcher's way of teaching, it is concluded that the students' vocabulary mastery was improved; consequently the action cycle objective met the criterion.

\section{Discussion}

Based on the data finding previously described, it can be stated that the classroom action research was successfully conducted. It is said so because the students' vocabulary improved although the learning process was conducted only up to 2 cycles. The success was evidenced through the means of the tests conducted, that is the Pre-test I, Post-test I, and Posttest II. Dakhi (2011a, 2011b) stated that the dynamics and changeability are the nature and inevitability of every living language. This concept acts as the empirical background of the change and improvement of the students' vocabulary mastery.

In the Pre-test I the mean score was 56.19. Based on the score category prevailed in SDN Karawang Kulon II such amount of scores was categorized 'Fair'. In the Post-test I of the Cycle I the students' scores were improved. It is indicated through the increase of the means gain from the Pre-test I and the Post-test I scores, that is 81.90 to 56.19. Nevertheless, the reseacher still disatisfied because there was still 1 student did not meet the minimal score criterion. Through the reflection, the researcher considered that the achievement could be optimally improved by improving the researcher's performances of teaching. This is in line with what Marbun (2017) and Grathia (2017) reported that their first cyle of the action research did not meet the criterion. 
In the Cycle II the students were found making making more significant improvement than that of the Cycle I. The improvement is indicated through the students' scores in the PosttestII, all the students reached and even above the minimum score, 80.00. Compared to the mean of the Post-test I score, the mean of the Post-test II obtained 12.39 score better. Based on the findings of the three mean increase, the researcher decided not to continue teaching to the next cycle.

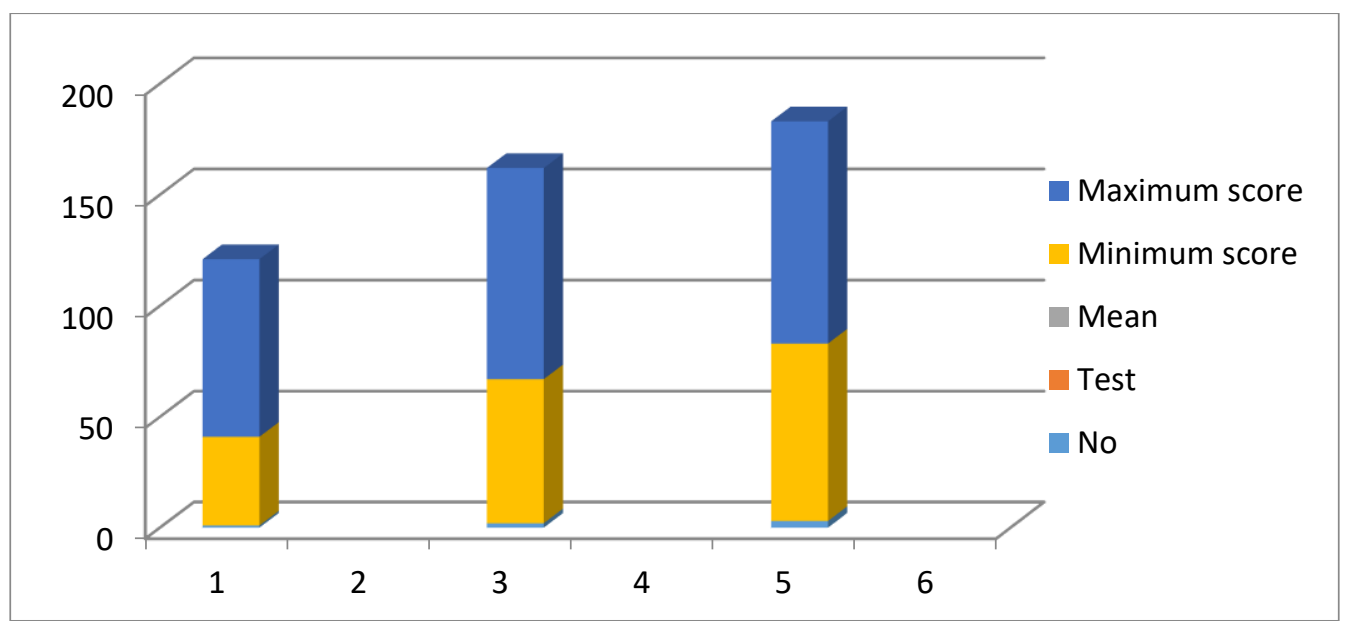

Graph 4.1. The Students' Mean Scores of Tests

The research finding support some previous studies on picture. Marshall, Pound, Whitethomsosn, and Pring (1989), for instnace, reported that there was significant effect of picture to experimental and control treatment of aphasic patients. Furthemore, Singh and Solmon (1990) confirmed that pictures inhibit some students' learning of new words. Cohen and Johnson (2011) Claimed that the imagery interventions facilitated the ease with which they learned the words. Imagery intervention according to them consists of Word Only, which involves the simple verbal presentation of a vocabulary word; Dual Coding, in which a picture was paired with the vocabulary word, and Image Creation, in which students were told to create a mental picture of the vocabulary word in their mind and draw it on paper.

The improvement of the students' vocabulary mastery has been answered by Albano (2013). He proposed some suggestions on how the pictures may be effective and impact the vocabulary mastery. They are as follows.

a. Predict. Students can look at picture or watch the first part of a video in order to predict what the topic of the lesson or activity will be about. 
b. Interact. The game Pictionary, in which players have to guess specific words based on their team mates' drawings and other mingling games with pictures are fun activities that can be used with children and adults to review the vocabulary they have learnt.

c. Create. Students can write or tell a story by using a sequence of pictures, or, if the teacher wants to really fire their imagination, the students can create a story based on a just single pictures.

d. Talk. At the beginner level, some students' faces go blank when they asked to answer a question. Teacher can avoid prolonged silence and prevent their students from feeling embarrassed by providing them with a picture. They can break the ice by asking the students to describe what they can see in the pictures

e. Understand. What is the easiest way to explain the meaning of a word? Show it through the classroom may be equipped, but they cannot hold everything. If there is an item or object to show to the students to help them remember the word for it, the teacher should try showing them a picture.

f. Reflect. Not only a picture give you the change to reflect on what $u$ see, but it also represents the opportunity to develop your other senses by considering what you can hear, smell and touch. This is a useful exercise for teachers who are preparing their students for students speaking exam.

g. Enact. In any class, there is usually someone who is shy or quiet. So how can you draw them out of themselves and encourage them to practice.

The second reason of the action success belongs to the picture advantages. Juliana (2013) described that a picture is worth a thousand words. This is true in a learning classroom as much as anywere else. To help learners really grasp a concept, pictures can visually represent the topic and area of learning taught. Using visual facilitation not only helps learners (to speak), but also makes easier for studensts them to remember the concept they have just learned. The simple pictures and the words about the topic offer an easy way for them to link the concept with the picture. 


\section{Conclusion}

The research finding convincingly draws conclusion into twofold. Firsly, depite the two-cycle-action of the study at SDN Karawang Kulon II, it supports the Juliana's picture advantage by which the students' vocabulary mastery got improved meeting the passing grade. Secondly, the observation and questionnaire result empirically show the positive leaner's learning attitude, an evidence for the picture usage effectiveness and advantage.

\section{Suggestions}

Based on the conclusion, the researcher needs to propose some to English teacher, especially those at SDN Karawang Kulon II and other researchers.

(1) To English teachers, the researcher highly recommends to use pictures in teaching students. It is due to the fact that object recognition is highly highlighted via a cascade of reflexive, largely feedforward computations that culminate in a powerful neuronal representation in the inferior temporal cortex of human brain (DiCarlo, Zoccolan \& Rust, 2012)

(2) The other researchers, the researcher expects the research finding to be taken into account as inputs or reference enrichment. Besides, the researcher finding is highly expected to be take, into further researches either on the same areas and media for more accurate results or on different areas for broader implementation and result in language teaching field.

(3) Referring to Hutabarat and Dakhi's finding (2018) concerned with language learning effectiveness, a lecturer's perspective, covering identity awareness, personal experience, motivation, linguistic awareness and application, and conceptual and mechanical competence provides a further research on the measure of the degree correlation between picture teaching media and language learning effectiveness. 


\section{References}

Albano, (2013) How English language teachers can use pictures in class, retrieved august 7 , 2017, from: http://www.britishcouncil.org

Cohen, M. T. \& Johnson, H. (2011). Improving the acquisition of novel vocabulary through the use of imagery interventions. Early Chldhood Educational Journal, Volume 38 (5), pp. 357-366. Retrieved from https://link.springer.com/article/10.1007/s10643-010-0408y\#citeas

Dakhi, S. (2016). Foreign language acquisition of souvenir seller in Bawomataluo village. RETORIKA: Jurnal Ilmu Bahasa, 2 (1), pp. 16-32. doi: 10.22225/jr.2.1.243.16-32

Dakhi, S. (2011a). Lexical changes of southern dialect of Li Niha. (Master's Thesis). Medan: Program Pascasarjana, Universitas Negeri Medan. Retrieved from http://digilib.unimed.ac.id/3219/

Dakhi, S. (2011b). Semantic changes of southern dialect of Li Niha: An evidence for its change. Jurnal Littera. Retrieved from https://www.academia.edu/36176012/SEMANTIC_CHANGES_OF_SOUTHERN_DIA LECT_OF_LI_NIHA

Dakhi, S. (2010). Nias language maintenance in the society and individual. Jurnal Linguistik Terapan, Volume 7 (1), pp. 24-31. Retrieved from https://www.academia.edu/32261456/NIAS_LANGUAGE_MAINTENANCE_IN_THE SOCIETY_AND_INDIVIDUAL

DiCarlo, J. J., occolan, D. \& Rust, N. C. (2012). How does the brain solve visual object recognition? Neuron, Volume 73, pp. 415-434. doi: 10.1016/j.neuron.2012.01.010

Ferrance, E. (2002) Action Research: Themes in Education. Northeast and Island Regional Education at Brown University. Retrieved from http://www.lab.brown.edu/pubs/thehe_ed/act_research

Grathia, E. (2017). The effect of using English video on students' vocabulary mastery at SMP PSKD 6 Depok. Journal of English Teaching, Volume 3 (2), pp. 143-151. Retrieved from http://ejournal.uki.ac.id/index.php/jet/article/view/706

Griva, E. (2009). Young learners' vocabulary strategies emplyoment in a foreign language. Retrieved August 4, 2017, from: http://ressources-cla.unv-fcomte.fr/gerflint/SE europeen2/griva.pdf

Hutabarat, H. \& Dakhi, S. (2018). Language effectiveness of undergraduate thesis. (Research Report). Jakarta: Universitas Kristen Indonesia. 
Juliana (2013). The benefits of visual Facilitation in the class room. Retrieved 8 August 2017, From: Http://www.trainingindustry.com'articles

Kim, Y. (2011). Current trends in ELT. Journal of English Teaching, Volume 1 (1), pp. 1-13. Retrieved from http://ejournal.uki.ac.id/index.php/jet/article/view/48

Marbun, S. M. H. (2017). Using TGT Technique to improve the seventh graders' English vocabulary. Journal of English Teaching, Volume 3 (1), pp. 65-84. Retrieved from http://ejournal.uki.ac.id/index.php/jet/article/view/700

Marshall, J., Pound, C., White-thomsosn, M., \& Pring, T. (1989). The use of picture/word matching tasks to assist word retrieval in aphasic patients. Aphasiology, Volume 4 (2), pp. 167-184. https://doi.org/10.1080/02687039008249068

McCarten, J. (2007). Teaching vocabulary. New York: Cambrige University Press.

Singh, N. N. \& Solman, R. T (1990). A stimulus control analysis of the picture-word problem in children who are mentally retared: The blocking effect. Journal of Applied Behaviour Anlysis, Volume 23 (4). https://doi.org/10.1901/jaba.1990.23-525 